\title{
Experimental evaluation of genomic DNA degradation rates for the pathogen Pseudogymnoascus destructans (Pd) in bat guano
}

\author{
Jenny Urbina ${ }^{\text {Corresp., } 1}$, Tara Chestnut ${ }^{2}$, Donelle Schwalm ${ }^{3}$, Jennifer Allen ${ }^{1}$, Taal Levi ${ }^{1}$ \\ ${ }^{1}$ Department of Fisheries and Wildlife, Oregon State University, Corvallis, Oregon, United States \\ 2 Mount Rainier National Park, National Park Service, Ashford, Washington, United States \\ 3 Department of Biology, University of Maine-Farmington, Farmington, Maine, United States \\ Corresponding Author: Jenny Urbina \\ Email address: jenny.gonzalez@oregonstate.edu
}

Pseudogymnoascus destructans (Pd), the causative agent of white-nose syndrome in bats (WNS), has led to dramatic declines of bat populations in eastern North America. In the spring of 2016, WNS was first detected at several locations in Washington State, USA, which has prompted the need for large scale surveillance efforts to monitor the spread of $\mathrm{Pd}$. Pd is typically detected in bats using invasive methods requiring capturing and swabbing individual bats. However, Pd can also be detected in guano, which may provide an efficient, affordable, and noninvasive means to monitor Pd in bats across North America. The widespread implementation of Pd surveillance in guano is hindered by substantial uncertainty about the probability of detecting Pd when present, and how this probability is influenced by the time since defecation, local environmental conditions, the amount of guano sampled, and the original concentration of DNA shed in the guano. In addition, the expected degradation rate of Pd DNA depends on whether the Pd DNA found in guano represents extracellular DNA fragments, intracellular DNA from dead Pd fungal cells, or from intracellular and viable Pd cells. While this is currently unknown, it has been posited that most environmental DNA, such as Pd found in guano long after defecation, is fragmented extracellular DNA. Using non-viable isolated DNA at precise quantities, we experimentally characterized the degradation rates of Pd DNA in guano samples. We spiked 450 guano samples with Pd gDNA in a 10-fold dilution series from 1 million to 1,000 $\mathrm{fg}$ and placed them in variable environmental conditions at five sites at Mount Rainier National Park in Washington State, which is a priority location for Pd surveillance. We evaluated DNA degradation over 70 days by quantifying the amount of DNA in samples collected every 14 days using real-time quantitative PCR (qPCR). Our sampling period was from July $10^{\text {th }}$ to September $17^{\text {th }} 2018$ which overlaps with bat movement between summer roosts as well as movement from maternity colonies fall swarms. We detected Pd DNA in PeerJ reviewing PDF | (2019:04:36780:1:1:NEW 8 Oct 2019) 
guano 56 and 70 days after inoculation with 1 million and 100,000 fg respectively, while the lowest quantity $(1,000 \mathrm{fg})$ was detected until 42 days. Detection probability was variable among sites and lower where samples were left exposed without overhead cover. If Pd is shed as extracellular DNA in guano at quantities above $1,000 \mathrm{fg}$, then guano collection is likely to provide an effective tool for environmental screening of Pd that can be employed in an early detection and rapid response framework throughout Washington and other regions where this disease is rapidly emerging. 


\section{Experimental evaluation of genomic DNA degradation rates for the pathogen}

2 Pseudogymnoascus destructans (Pd) in bat guano

3

4

5

6

$7 \quad{ }^{1}$ Department of Fisheries and Wildlife, Oregon State University, Corvallis, OR, USA

$8{ }^{2}$ Mount Rainier National Park, National Park Service, Ashford, WA, USA

$9{ }^{3}$ Department of Biology, University of Maine-Farmington, Farmington, ME, USA 10

11

12 Corresponding Author:

13 Jenny Urbina ${ }^{1}$

142820 SW Campus Way, 104 Nash Hall, Corvallis, OR, 97331, USA

15 Email address: jenny.gonzalez@oregonstate.edu 


\section{Abstract}

18 Pseudogymnoascus destructans (Pd), the causative agent of white-nose syndrome in bats (WNS),

19 has led to dramatic declines of bat populations in eastern North America. In the spring of 2016,

20 WNS was first detected at several locations in Washington State, USA, which has prompted the

21 need for large scale surveillance efforts to monitor the spread of $\mathrm{Pd}$. Pd is typically detected in

22 bats using invasive methods requiring capturing and swabbing individual bats. However, Pd can

23 also be detected in guano, which may provide an efficient, affordable, and noninvasive means to

24 monitor Pd in bats across North America. The widespread implementation of Pd surveillance in

25 guano is hindered by substantial uncertainty about the probability of detecting Pd when present,

26 and how this probability is influenced by the time since defecation, local environmental

27 conditions, the amount of guano sampled, and the original concentration of DNA shed in the

28 guano. In addition, the expected degradation rate of Pd DNA depends on whether the Pd DNA

29 found in guano represents extracellular DNA fragments, intracellular DNA from dead Pd fungal

30 cells, or from intracellular and viable Pd cells. While this is currently unknown, it has been

31 posited that most environmental DNA, such as Pd found in guano long after defecation, is

32 fragmented extracellular DNA. Using non-viable isolated DNA at precise quantities, we

33 experimentally characterized the degradation rates of Pd DNA in guano samples. We spiked 450

34 guano samples with Pd gDNA in a 10-fold dilution series from 1 million to 1,000 fg and placed

35 them in variable environmental conditions at five sites at Mount Rainier National Park in

36 Washington State, which is a priority location for Pd surveillance. We evaluated DNA

37 degradation over 70 days by quantifying the amount of DNA in samples collected every 14 days

38 using real-time quantitative PCR (qPCR). Our sampling period was from July $10^{\text {th }}$ to September

$3917^{\text {th }} 2018$ which overlaps with bat movement between summer roosts as well as movement from

40 maternity colonies fall swarms. 
41 We detected Pd DNA in guano 56 and 70 days after inoculation with 1 million and 100,000 fg

42 respectively, while the lowest quantity (1,000 fg) was detected until 42 days. Detection

43 probability was variable among sites and lower where samples were left exposed without

44 overhead cover. If Pd is shed as extracellular DNA in guano at quantities above 1,000 fg, then

45 guano collection is likely to provide an effective tool for environmental screening of Pd that can

46 be employed in an early detection and rapid response framework throughout Washington and

47 other regions where this disease is rapidly emerging.

\section{Introduction}

49 Emerging infectious diseases (EIDs) are one of many drivers of the current biodiversity crisis

50 (Harvell et al., 1999; Daszak, Cunningham \& Hyatt, 2003; Tompkins et al., 2015; Cunningham,

51 Daszak \& Wood, 2017; Reid et al., 2019). In eastern North America, white-nose syndrome

52 (WNS) is among the most dramatic of recent emergence events. WNS, which is caused by the

53 psychrophilic fungus Pseudogymnoascus destructans (Pd), has led to unprecedented mortality of

54 hibernating bats (Reeder \& Moore, 2013) and now threatens several species with regional

55 extinction (Frick et al., 2010, 2017). The emergence of Pd in North America was first reported

56 from New York in 2006 and has since spread to 38 states and 7 Canadian provinces

57 (www.whitenosesyndrome.org, accessed September 15, 2019). Pd has been confirmed in 20 bat

58 species from the United States and Canada, including two endangered and one threatened species

59 (www.whitenosesyndrome.org, accessed September 15, 2019). The first case of WNS in western

60 North America was detected in 2016 (Lorch et al., 2016) in King County, Washington from a

61 little brown bat (Myotis lucifugus) and a silver-haired bat (Lasionycteris noctivagans) tested

62 positive for the fungus but had no clinical signs of the disease (https://wdfw.wa.gov/species-

63 habitats/diseases/bat-white-nose\#, accessed September 15, 2019). In April 2017, Pd was 
64 confirmed from a Yuma myotis bat (Myotis yumanensis) in King County, followed by Pd 65 detections from two little brown bats and two Yuma myotis in Lewis County, Washington in 66 May 2017 with no indication of disease. In 2018, Pd and WNS were confirmed in little brown 67 bats and Yuma myotis from several additional sites in King County. Recently, in March 2019, 68 WNS was confirmed positive for the first time in North America in a western long-eared myotis 69 (Myotis evotis), and the first case of WNS outside of King County was confirmed from a little 70 brown bat in Pierce County.

71 Efforts to document the spread and impacts on WNS typically employ methods that include 72 capture and handling of individual bats to collect skin swabs to test for Pd presence, and 73 collecting skin biopsies when clinical signs of WNS are observed. Alternatively, noninvasive 74 detection from guano can be used to detect the presence of pathogens (Kriger, Hero \& Ashton, 75 2006; Oehm et al., 2011) like Pd (Langwig et al., 2016; Dobony \& Johnson, 2018). Pd in guano 76 can be isolated and quantified with methods such as real-time qPCR or droplet digital PCR 77 (Lorch et al., 2013). Guano samples can additionally be used to identify the species of bat host, 78 which can be difficult to determine by morphology alone (Höss et al., 1992; Kurose, Masuda \& 79 Tatara, 2005; Player et al., 2017), as well as bat diet (Walker et al., 2016).

80 The widespread implementation of Pd surveillance in guano is hindered by substantial 81 uncertainty about the probability of detecting Pd when present, and how this probability is 82 influenced by the time since defecation, local environmental conditions, the amount of guano 83 sampled, and the original concentration of DNA shed in the guano. In addition, the expected 84 degradation rate of Pd DNA depends on whether the Pd DNA found in guano represents 85 extracellular DNA fragments, intracellular DNA from dead Pd fungal cells, or from intracellular 86 and viable Pd cells. While this is currently unknown, it is posited that most environmental DNA, 
87 such as Pd found in guano long after defecation (Brownlee-Bouboulis \& Reeder, 2013), is

88 fragmented extracellular DNA, which can persist for long periods when bound to soil colloids 89 and partially protected from degradation (Agnelli et al., 2007).

90 To inform interpretation of noninvasive surveillance of Pd using guano, we used experimental 91 guano inoculation in natural field settings to assess the probability of detecting Pd DNA and the 92 rate of DNA degradation. The objective of this experiment was to understand how long we can 93 detect extracellular Pd DNA in bat guano and how environmental factors affect detection. We 94 evaluated DNA degradation over 70 days by quantifying the amount of DNA samples collected 95 every 14 days. We hypothesized probability of detection of Pd would decrease over time, and 96 would vary based on the mass of collected sample, and exposure to ambient conditions. The 97 results of our study will inform the development of future protocols and monitoring actions for 98 bats and $\mathrm{Pd} / \mathrm{WNS}$ spread.

101

\section{Materials \& Methods}

\section{Experimental setup}

Five different locations in Mount Rainier National Park were selected as representative regions where active bat monitoring is occurring (Figure 1). All locations were buildings and structures that were occupied by bats. Two sites were in the Nisqually River watershed, two in the Ohanapecosh River watershed and one was in the Carbon River watershed. Sites were categorized as exposed or protected according to the presence of structures shielding guano samples from direct solar radiation or rain. Two sites, in the Carbon and Nisqually watersheds, were protected with an overhead cover to avoid sun exposure and rain, while the remaining sites were completely exposed (Figure 1). The regional weather in the study area during our study 
110 presented the following conditions: Temperature average low $=5.6 \mathrm{C}$ and average high $=16 \mathrm{C}$,

111 with a rainfall between 5 and $10 \mathrm{~cm}$ (www.ncdc.noaa.gov/climate-information).

112 We collected bat guano from the attic of a storage barn belonging to Oregon State University in

113 Corvallis, OR. The guano was tested for Pd prior to installation of the experiment and autoclaved

114 as a precautionary measure to prevent potential harboring of active Pd and other pathogens. We

115 measured 1 gram (SD 0.018g) of guano and placed each sample in individual petri dishes. One

116 milliliter of genomic DNA (gDNA) (ATCC MYA-4855D) was spiked onto the guano in 10-fold

117 serial dilutions ranging from 1 million fg to $1,000 \mathrm{fg}$, including a negative control. After pouring

118 the inoculum, samples were swirled to spread the inoculum evenly on the guano pellets. Each

119 concentration was prepared in triplicate for a total of 15 samples per site. We placed the 15 petri

120 dishes in identical trays at each site, started our sampling on day zero (deployment day) and

121 continued sampling every 14 days, ending on day 70 . Trays were placed on the ground, outside

122 of buildings and structures where bats have been reported but adjacent to locations where bats

123 exited to ensure cross-contamination did not occur. Each tray was also labeled with a sign visible

124 from 3 meters indicating "Research in Progress - Do Not Disturb" to ensure the experiment was

125 not disturbed by visitors or workers. We thus collected 15 samples per each of five sites during

126 six different sampling events from July $10^{\text {th }} 2018$ and September $17^{\text {th }} 2018$ for a total of 450

127 fecal samples (mean $=0.13 \pm 0.06 \mathrm{~g} / \mathrm{sample}$ ). At each site, we wore a new pair of gloves for each

128 concentration to collect the pellets to avoid cross contamination among different concentrations.

129 Collected samples were placed in $2.0 \mathrm{~mL}$ Eppendorf safe-lock tubes and stored on ice.

130 Immediately after each sampling event, samples were shipped overnight to Oregon State

131 University where they were stored at $-20{ }^{\circ} \mathrm{C}$ until DNA extraction.

132 Quantifying gDNA 
133 DNA was extracted from fecal pellets using the DNeasy PowerLyzer Powersoil Kit following

134 the manufacturer's instructions. One extraction blank was included with each batch every 25

135 samples to be used as non-template controls. Mass of all guano samples was measured prior to

136 extraction with an average of $0.13 \pm 0.06 \mathrm{~g}$. DNA was amplified in a probe-based assay targeting

137 the intergenic spacer (IGS) region of Geomyces destructans (Muller et al, 2013). Reactions

138 consisted of 12.5 ul TaqMan Environmental MasterMix 2.0 (Life Technologies, Carlsbad, CA),

139 forward primer nu-IGS-0169-5' Gd and reverse primer nu-IGS-0235-3' Gd at a final

140 concentration of $400 \mathrm{nM}$, TaqMan FAM-labeled probe at a final concentration of $200 \mathrm{nM}$ and 5

$141 \mu \mathrm{l}$ of DNA template. Using Pd gDNA, we prepared a 4-point standard curve, diluted 10-fold,

142 with the highest concentration containing 1,000 fg gDNA and the lowest point containing $1 \mathrm{fg}$

143 DNA. The quantification of DNA was performed using an ABI PRISM 7500 Fast real-time PCR

144 system (Applied Biosystems, Foster City, CA) with the following cycling conditions: initial

145 activation $95{ }^{\circ} \mathrm{C}$ for $10 \mathrm{~min}$; denaturation $95^{\circ} \mathrm{C}$ for $15 \mathrm{~s}$ and annealing, and extension $60{ }^{\circ} \mathrm{C}$ for

$14660 \mathrm{~s}$, with a total of 40 cycles.

147 All standards were run in triplicate to generate reference curves to control for consistency across

148 plates and check for variation that can be caused by low amounts of template (Verant et al.,

149 2016). Amplification efficiency of qPCR reactions calculated as an average across all plates was

$15090 \%$. This lower percentage is due to high variation coming from our lowest standard $1 \mathrm{fg}$. We

151 analyzed all samples collected in triplicate, and they were reported as positive when 2 out of the

1523 wells amplified within 40 cycles. Our limit of quantification corresponded to $37 \mathrm{Ct}$ value of

153 our lowest standard (1 fg). However, our limit of detection was up to $39 \mathrm{Ct}$ as we detected

154 amplification for the target $\mathrm{Pd}$ sequence at this higher $\mathrm{Ct}$ value. No amplification was seen in the

155 extraction blanks. All analyses were done using an ABI 7300 real-time PCR system. 
157 We evaluated both the rate of DNA degradation and the change in the probability of detection

158 through time. To evaluate the rate of DNA degradation, we used log-transformed DNA quantity

159 as measured with qPCR as the dependent variable in a linear model with normal error

160 distribution. To facilitate log-transformation, we added 0.195 fg to all DNA concentrations,

161 which represents the lower limit of detection using qPCR. To evaluate the change in the

162 probability of detection, we used logistic regression with $\mathrm{Pd}$ positive/negative status as the

163 dependent variable. In both models, our predictors included the initial quantity of the inoculum

164 (categorical with four levels), field site where inoculated guano was placed (categorical with five

165 levels), days since inoculation (continuous), mass of guano sampled (continuous), and an

166 interaction term for days since inoculation and site to account for variable rates of DNA

167 degradation by site. Based on our model for DNA quantity through time, we projected the

168 expected measured Pd quantity for 100 days since deposition, across the four initial

169 concentrations and five sampling locations, each with its own degradation rate to characterize the

170 variable rate of degradation among sites. All statistical analyses were performed in R (Version

171 3.4.1, 2017-06-30) using packages plyr, magrittr, ggplot2 and cowplot (Wickham, 2011, 2016;

172 Milton \& Wickham, 2014; Wilke, 2019)

173

174 Results

175 Quantity of Pd DNA in guano decreased through time with different decay rates among sites

176 (Figure 2). The rate of degradation varied from 1.6\% (Nisqually Site 1) up to 8.2\%

177 (Ohanapecosh Site 2). Degradation rates at the protected sites (i.e., Nisqually Site 1 1.6\% and

178 Carbon Site 2.9\%) were lower than those in unprotected sites (i.e., Nisqually Site 2 and 
179 Ohanapecosh Site 1 and 2), which presented a higher degradation rate through time (Rate

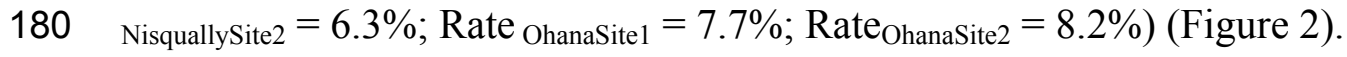

181 Samples inoculated with the two highest quantities (1 million fg and 100,000 fg) amplified

182 during all sampling events at all sites (Figure 3 and Table 1). After 70 days, 10 and 8 out of 15

183 samples (66 and 53\%) amplified (Table 1). During the first sampling event, we detected Pd DNA

184 from 9 out of 15 samples (60\%) inoculated with the lowest quantity (1,000 fg) amplified in 4 out

185 of 5 sites. After 13 days, the probability of detection in the lowest initial quantity decreased to

$1866 \%$, with amplification from 1 of 15 samples (Figure 4). However, we observed variation in

187 detection probability based on the site. We detected Pd in samples inoculated with our lowest

188 quantity (1,000 fg) at Nisqually Site 2 for 30 days, and the Carbon Site 1 for 42 days. We found

189 evidence that the probability of detection is explained by the interaction between sampling time

190 and site for 3 out of the 5 sites $\left(\beta_{\text {NisquallySite } 2}=-0.108 ; P=>0.0001, \beta_{\text {OhanaSite1 }}=-0.09\right.$;

$\left.191 P=>0.0001, \beta_{\text {OhanaSite } 2}=-0.011 ; P=>0.0001\right)$ (Table 2). Mass had a significant effect on the

192 amount of DNA detected $(\beta=6.93 ; P=>0.0001)$ and in the positive detection of samples $(\beta=$

$1937.58 ; P=0.0001)$. All controls were negative for Pd amplification. Projections based on the

194 models suggested that although DNA degradation rates vary among sites, it is possible to detect

195 extracellular Pd after 100 days for samples initially inoculated with the highest quantities (1

196 million and $100,000 \mathrm{fg})$ or approximately 80 days for the lowest quantities $(10,000$ and $1,000 \mathrm{fg})$

197 of Pd DNA (Figure 5).

198 Discussion

199

200

Pd is a continued threat to bat populations and diversity as it spreads across North

201 America (Alves, Terribile \& Brito, 2014). The most recent report of Pd and WNS in the western 
202 United States from July 2019 suggests Pd is spreading and common species unique to western

203 North America are vulnerable to WNS, e.g., western long-eared myotis. Testing for WNS can be

204 done with invasive methods such as capturing and swabbing individual bats and collecting tissue

205 biopsies from the wings to confirm infection, but this can be expensive, time consuming,

206 requires specialized animal handling training and vaccinations, and imposes stress to the animal

207 and a risk of unhealed lesions. If sufficiently effective, noninvasive monitoring of Pd DNA using

208 guano could save time and costs to allow for larger surveillance efforts for early Pd detection

209 while avoiding handling of bats. While noninvasive monitoring does not confirm disease status,

210 it can be a useful tool to mobilize early detection and rapid response strategies. DNA in guano

211 degrades through time in a manner affected by exposure to the ambient environment that varies

212 among sites (Verant et al., 2018). Here our goal was to establish baseline expectations of

213 degradation rates and detectability of extracellular Pd DNA in guano left under ambient

214 environmental conditions near the colonizing front of Pd in western North America.

Quality of DNA that can be recovered from bat guano samples varies through time.

216 Samples collected more than 10 years prior to the time of analysis delivered less DNA (Zinck,

217 Duffield \& Ormsbee, 2004) than samples that have been just recently collected (Vege \&

218 McCracken, 2001). In our study, a higher proportion of samples collected during the first

219 sampling events amplified, after which amplification declined until the end of the experiment.

220 Degradation of extracellular DNA depends on environmental conditions such as the level of

221 water, oxygen and temperature (Willerslev, Hansen \& Poinar, 2004). In this study, the initial

222 quantity of inoculum and mass were variables related to the probability of DNA detection

223 through time. Samples inoculated with the highest quantities successfully amplified from all

224 sampling events while samples initially inoculated with lowest quantities (10,000 and 1,000 fg) 
225 amplified in lower proportions. If a sample of $\sim 0.14 \mathrm{~g}$ is sampled from $\sim 1 \mathrm{~g}$ of guano inoculated 226 with the lowest quantity used in this experiment $(1,000 \mathrm{fg})$ the total amount that can be detected 227 will be $\sim 140 \mathrm{fg}$. However, using our results we estimated that detection can be as low as $1.15 \mathrm{fg}$ 228 for one of the sites. The amount of DNA that can be detected changed among sites and sampling 229 events.

We found that extracellular Pd DNA in summer can be detected for up to 42 days when 231 inoculated at 1,000 fg, and for up to 70 days after deployment with estimates indicating DNA can be detected for approximately 100 days if initial deposition quantities are among our higher inoculations ( 1 million and 100,000 fg). In our study, DNA degraded faster in sites exposed to sunlight without overhead cover. Exposure to direct solar radiation can result in DNA degradation by denaturation in exposed samples (Schuch et al., 2017). Similarly, high temperatures generated by direct radiation can drive a high degradation of DNA in contrast to low temperatures (Nagler et al., 2018). In contrast to cold environments where nucleic acids can 238 be stored for long-term due to the decrease of reaction rates by an order of magnitude for every degree drop in temperature (Smith et al., 2001).

241 the amount reported by Verant et al., (2018) (0.28 fg) from a study done in hibernacula

242 sediments. The amounts of Pd reported from guano and sediments were lower than loads

243 reported from bat swabs and tissue samples. During hibernation Langwig et al., (2015) reported

244 loads between $1000-10 \mathrm{fg}$ and loads during swarming and maternity as low as $1 \mathrm{fg}$. However, 245 different species can show different maximum fungal loads through time (Langwig et al., 2016; 246 Frick et al., 2017). Pd in guano is hypothesized to originate from ingestion of the fungus by bats 247 during grooming, as bats with the disease groom more often than uninfected bats. As Pd seems to 
248 resist gastrointestinal passing, movement of bats between hibernacula can lead to disperse of Pd

249 spores to new locations (Brownlee-Bouboulis \& Reeder, 2013; Ballmann et al., 2017). As

250 degradation of DNA can be affected by environmental variables that change per location, we

251 recommend use of an integrated approach that includes monitoring of multiple sites and their

252 environmental variables to inform agencies and managers about the role those variables are

253 playing on the rates of DNA degradation, and how it affects monitoring and surveillance studies.

254 Properly designed sampling of hosts and their pathogens will improve our chances for an early

255 detection of Pd in bats and potential emergence in new areas. Wildlife disease surveillance must

256 provide information for agencies in a timely manner to be able to generate appropriate

257 management actions especially in the case of novel pathogens (Sleeman et al., 2019).

\section{Conclusions}

259 Throughout this study, we provided experimental evidence that validate the detection of

$260 \mathrm{Pd}$ in guano as an effective non-invasive technique for pathogen surveillance. The probability of

261 Pd detection in guano is affected by environmental factors that are site specific as well as initial

262 quantity of inoculum and sampled mass. There is still a need to determine the source of Pd DNA

263 detected in guano as it could be extracellular DNA fragments, intracellular dead Pd cells, or

264 intracellular viable Pd cells, that can affect the time of degradation and the probability of

265 detection. If positive results of $\mathrm{Pd}$ are detected, we recommend including and notifying the

266 records immediately at www.whitenosesyndrome.org_as well as to the Fisheries and Wildlife unit 267 working in your locality. 
270 We owe thanks to the bat monitoring team at Mount Rainier National Park (Alaiya Cave, Dacey

271 Clark, Alexis Levorse, Colin Woodbury) for their effort sampling bats in the park, for their input,

272 and for the provisioning of samples. Thank you to the Levi and Garcia lab at Oregon State

273 University for the use of their lab equipment. 


\section{References}

275 Agnelli A, Ascher J, Corti G, Ceccherini MT, Pietramellara G, Nannipieri P. 2007. Purification 276 and isotopic signatures $(\delta 13 \mathrm{C}, \delta 15 \mathrm{~N}, \Delta 14 \mathrm{C})$ of soil extracellular DNA. Biology and 277 Fertility of Soils 44:353-361. DOI: 10.1007/s00374-007-0213-y.

278 Alves DMCC, Terribile LC, Brito D. 2014. The Potential Impact of White-Nose Syndrome on 279 the Conservation Status of North American Bats. PLOS ONE 9:e107395. DOI: 10.1371/journal.pone.0107395.

281

282

283

284

285

286

287

288

289

290

291

292

293

294

295

Ballmann AE, Torkelson MR, Bohuski EA, Russell RE, Blehert DS. 2017. Dispersal hazards of Pseudogymnoascus destructans by bats and human activity at hibernacula in summer. Journal of Wildlife Diseases 53:725-735. DOI: 10.7589/2016-09-206.

Brownlee-Bouboulis SA, Reeder DM. 2013. White-nose syndrome-affected little brown myotis (Myotis lucifugus) increase grooming and other active behaviors during arousals from hibernation. Journal of Wildlife Diseases 49:850-859. DOI: 10.7589/2012-10-242.

Cunningham AA, Daszak P, Wood JLN. 2017. One Health, emerging infectious diseases and wildlife: two decades of progress? Philosophical Transactions of the Royal Society B: Biological Sciences 372. DOI: 10.1098/rstb.2016.0167.

Daszak P, Cunningham AA, Hyatt AD. 2003. Infectious disease and amphibian population declines. Diversity and Distributions 9:141-150. DOI: 10.1046/j.14724642.2003.00016.x.

Dobony CA, Johnson JB. 2018. Observed Resiliency of Little Brown Myotis to Long-Term White-Nose Syndrome Exposure. Journal of Fish and Wildlife Management 9:168-179. DOI: 10.3996/102017-JFWM-080. 
296 Frick WF, Cheng TL, Langwig KE, Hoyt JR, Janicki AF, Parise KL, Foster JT, Kilpatrick AM. 297 2017. Pathogen dynamics during invasion and establishment of white-nose syndrome 298

299

300

301

302

303

304

305

306

307

308

309

310

311

312

313

314

315

316

317

318 explain mechanisms of host persistence. Ecology 98:624-631. DOI: 10.1002/ecy.1706.

Frick WF, Pollock JF, Hicks AC, Langwig KE, Reynolds DS, Turner GG, Butchkoski CM, Kunz TH. 2010. An Emerging Disease Causes Regional Population Collapse of a Common North American Bat Species. Science 329:679. DOI: 10.1126/science.1188594.

Harvell CD, Kim K, Burkholder JM, Colwell RR, Epstein PR, Grimes DJ, Hofmann EE, Lipp EK, Osterhaus ADME, Overstreet RM, Porter JW, Smith GW, Vasta GR. 1999. Emerging Marine Diseases--Climate Links and Anthropogenic Factors. Science 285:1505-1510. DOI: 10.1126/science.285.5433.1505.

Höss M, Kohn M, Pääbo S, Knauer F, Schröder W. 1992. Excrement analysis by PCR. Nature 359:199.

Kriger KM, Hero J-M, Ashton KJ. 2006. Cost efficiency in the detection of chytridiomycosis using PCR assay. Diseases of Aquatic Organisms 71:149-154.

Kurose N, Masuda R, Tatara M. 2005. Fecal DNA Analysis for Identifying Species and Sex of Sympatric Carnivores: A Noninvasive Method for Conservation on the Tsushima Islands, Japan. Journal of Heredity 96:688-697. DOI: 10.1093/jhered/esi124.

Langwig KE, Frick WF, Reynolds R, Parise KL, Drees KP, Hoyt JR, Cheng TL, Kunz TH, Foster JT, Kilpatrick AM. 2015. Host and pathogen ecology drive the seasonal dynamics of a fungal disease, white-nose syndrome. Proceedings of the Royal Society B: Biological Sciences 282. DOI: 10.1098/rspb.2014.2335.

Langwig K, Frick, Winifred F., Hoyt Joseph R., Parise Katy L., Drees Kevin P., Kunz Thomas H., Foster Jeffrey T., Kilpatrick A. Marm. 2016. Drivers of variation in species impacts 
for a multi-host fungal disease of bats. Philosophical Transactions of the Royal Society B: Biological Sciences 371:20150456. DOI: 10.1098/rstb.2015.0456.

321

Lorch JM, Muller LK, Russell RE, O’Connor M, Lindner DL, Blehert DS. 2013. Distribution and Environmental Persistence of the Causative Agent of White-Nose Syndrome, Geomyces destructans, in Bat Hibernacula of the Eastern United States. Applied and Environmental Microbiology 79:1293-1301. DOI: 10.1128/AEM.02939-12.

Lorch JM, Palmer JM, Lindner DL, Ballmann AE, George KG, Griffin K, Knowles S, Huckabee JR, Haman KH, Anderson CD, Becker PA, Buchanan JB, Foster JT, Blehert DS. 2016. First Detection of Bat White-Nose Syndrome in Western North America. mSphere 1. DOI: $10.1128 / \mathrm{mSphere} .00148-16$.

Milton B, Wickham H. 2014. magrittr: A Forward-Pipe Operator for R.

Nagler M, Insam H, Pietramellara G, Ascher-Jenull J. 2018. Extracellular DNA in natural environments: features, relevance and applications. Applied Microbiology and Biotechnology 102:6343-6356. DOI: 10.1007/s00253-018-9120-4.

Oehm J, Juen A, Nagiller K, Neuhauser S, Traugott M. 2011. Molecular scatology: how to improve prey DNA detection success in avian faeces? Molecular Ecology Resources 11:620-628. DOI: 10.1111/j.1755-0998.2011.03001.x.

Player D, Lausen C, Zaitlin B, Harrison J, Paetkau D, Harmston E. 2017. An alternative minimally invasive technique for genetic sampling of bats: Wing swabs yield species identification. Wildlife Society Bulletin 41:590-596. DOI: 10.1002/wsb.803.

Reeder DM, Moore MS. 2013. White-Nose Syndrome: A Deadly Emerging Infectious Disease of Hibernating Bats. In: Adams RA, Pedersen SC eds. Bat Evolution, Ecology, and 
341

342

343

344

345

346

347

348

349

350

351

352

353

354

355

356

357

358

359

360

361

362

363

Conservation. New York, NY: Springer New York, 413-434. DOI: 10.1007/978-1-46147397-8_20.

Reid AJ, Carlson AK, Creed IF, Eliason EJ, Gell PA, Johnson PTJ, Kidd KA, MacCormack TJ, Olden JD, Ormerod SJ, Smol JP, Taylor WW, Tockner K, Vermaire JC, Dudgeon D, Cooke SJ. 2019. Emerging threats and persistent conservation challenges for freshwater biodiversity. Biological Reviews 94:849-873. DOI: 10.1111/brv.12480.

Schuch AP, Moreno NC, Schuch NJ, Menck CFM, Garcia CCM. 2017. Sunlight damage to cellular DNA: Focus on oxidatively generated lesions. Oxidative DNA Damage \& Repair 107:110-124. DOI: 10.1016/j.freeradbiomed.2017.01.029.

Sleeman JM, Blehert DS, Richgels KLD, White CL. 2019. Response to "Prepublication Communication of Research Results": The Need for a Coordinated Wildlife Disease Surveillance Laboratory Network. EcoHealth 16:4-6. DOI: 10.1007/s10393-019-013965.

Smith CI, Chamberlain AT, Riley MS, Cooper A, Stringer CB, Collins MJ. 2001. Not just old but old and cold? Nature 410:771-772. DOI: 10.1038/35071177.

Tompkins DM, Carver S, Jones ME, Krkošek M, Skerratt LF. 2015. Emerging infectious diseases of wildlife: a critical perspective. Trends in Parasitology 31:149-159. DOI: 10.1016/j.pt.2015.01.007.

Vege S, McCracken GF. 2001. Microsatellite genotypes of big brown bats (Eptesicus fuscus: Vespertilionidae, Chiroptera) obtained from their feces. Acta Chiropterologica 3:237244.

Verant ML, Bohuski Elizabeth A., Richgels Katherine L. D., Olival Kevin J., Epstein Jonathan H., Blehert David S., McCallum Hamish. 2018. Determinants of Pseudogymnoascus 
364

365

366

367

368

369

370

371

372

373

374

375

376

377

378

379

380

381

382

383

destructans within bat hibernacula: Implications for surveillance and management of white-nose syndrome. Journal of Applied Ecology 55:820-829. DOI: 10.1111/13652664.13070.

Verant M, Bohuski E, Lorch J, Blehert D. 2016. Optimized methods for total nucleic acid extraction and quantification of the bat white-nose syndrome fungus, Pseudogymnoascus destructans, from swab and environmental samples. Journal of Veterinary Diagnostic Investigation 28:110-118. DOI: 10.1177/1040638715626963.

Walker FM, Williamson CHD, Sanchez DE, Sobek CJ, Chambers CL. 2016. Species From Feces: Order-Wide Identification of Chiroptera From Guano and Other Non-Invasive Genetic Samples. PLOS ONE 11:e0162342. DOI: 10.1371/journal.pone.0162342.

Wickham H. 2011. The Split-Apply-Combine Strategy for Data Analysis. Journal of Statistical Software. 40:1-29.

Wickham H. 2016. ggplot2: Elegant Graphics for Data Analysis.

Wilke C. 2019. cowplot: Streamlined Plot Theme and Plot Annotations for "ggplot2."

Willerslev E, Hansen AJ, Poinar HN. 2004. Isolation of nucleic acids and cultures from fossil ice and permafrost. Trends in Ecology \& Evolution 19:141-147. DOI: 10.1016/j.tree.2003.11.010.

Zinck JM, Duffield DA, Ormsbee PC. 2004. Primers for identification and polymorphism assessment of Vespertilionid bats in the Pacific Northwest. Molecular Ecology Notes 4:239-242. DOI: 10.1111/j.1471-8286.2004.00629.x. 
Figure 1

Locations of experiment deployment at five occupied bat colonies in three watersheds in Mount Rainier National Park, Washington State, USA.

Identified by $10^{\text {th }}$ field Hydrological Unit Code (HUC): Carbon River HUC 1711001401, Cowlitz River HUC 1708000401, Nisqually River HUC 1711001501. Data Sources: US Geological Survey, National Park Service, ESRI. 


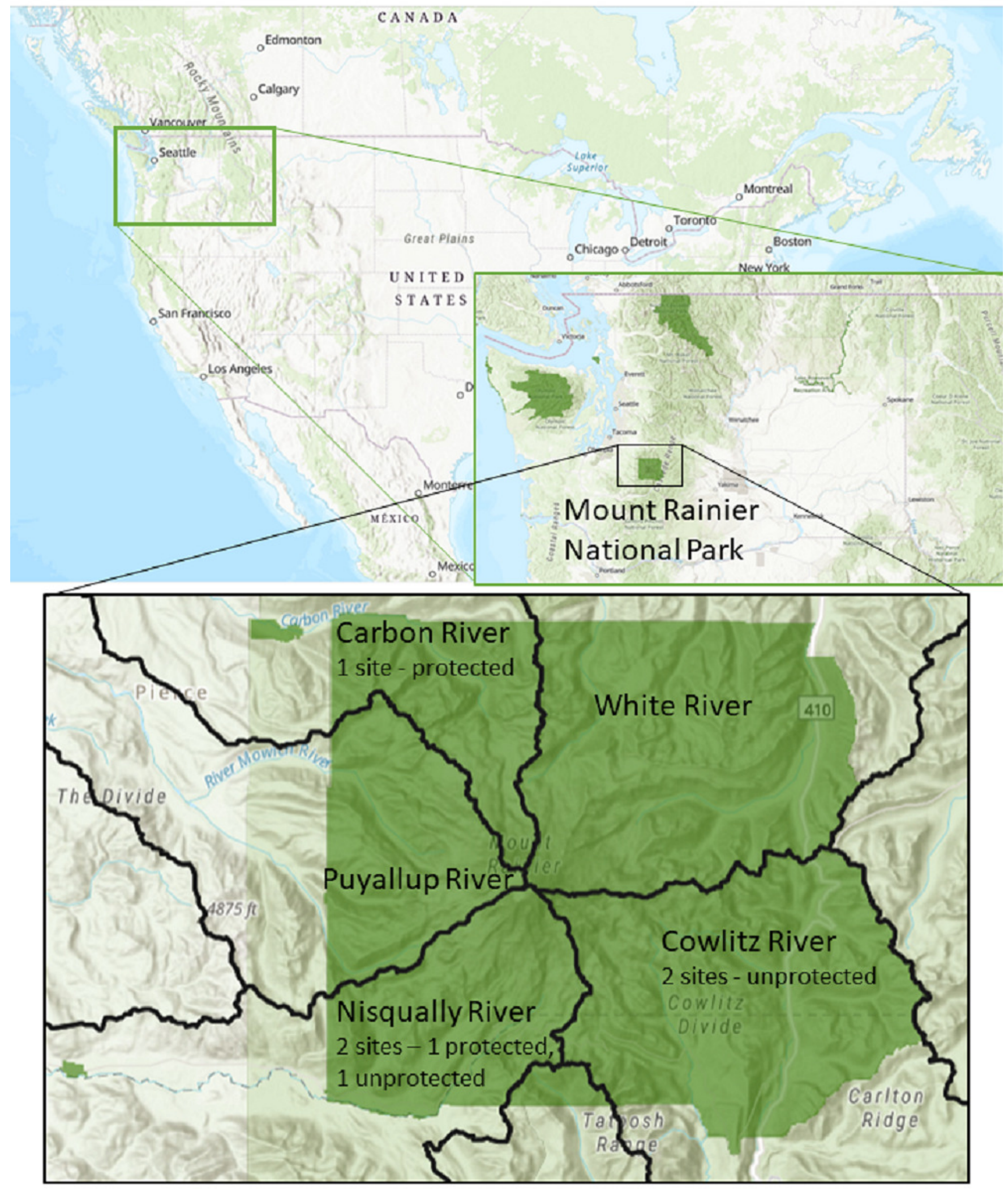


Figure 2

DNA quantity of Pseudogymnoascus destructans for all experimental sites sampled during 6 different times.

Highest inoculation quantity ( 1 million $\mathrm{fg}$ ) is represented by dark blue bars. Lowest inoculation quantity $(1,000 \mathrm{fg})$ is represented by the light blue bars.

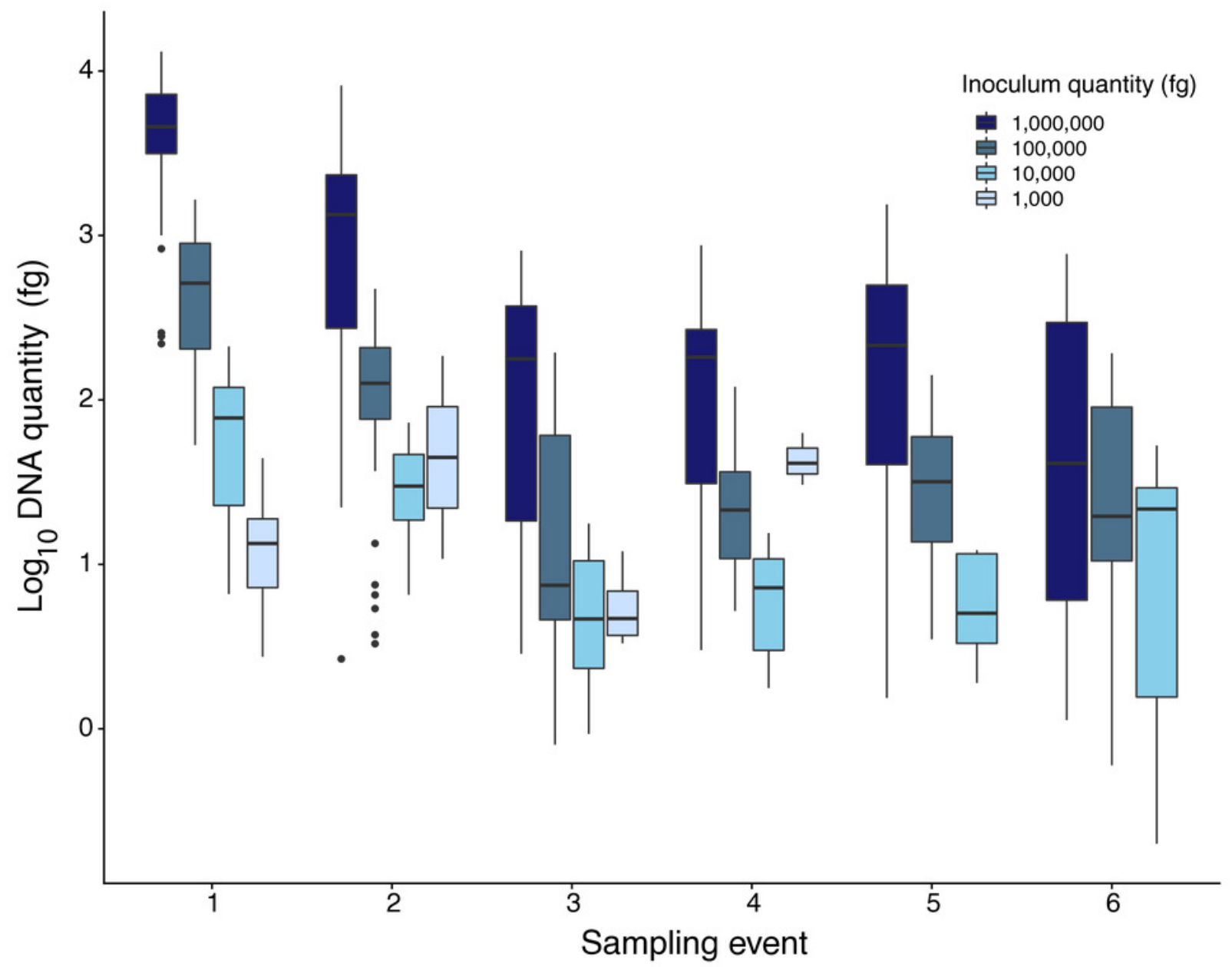


Figure 3

Comparison of Pseudogymnoascus destructans DNA quantities recovered from samples inoculated with 1 million and 100,000 fg among all sampling sites (indicated by caps letters).

Sites A and B were protected sites, with less exposure to wind and solar radiation while sites C, D, and E, were more exposed to wind and solar radiation.
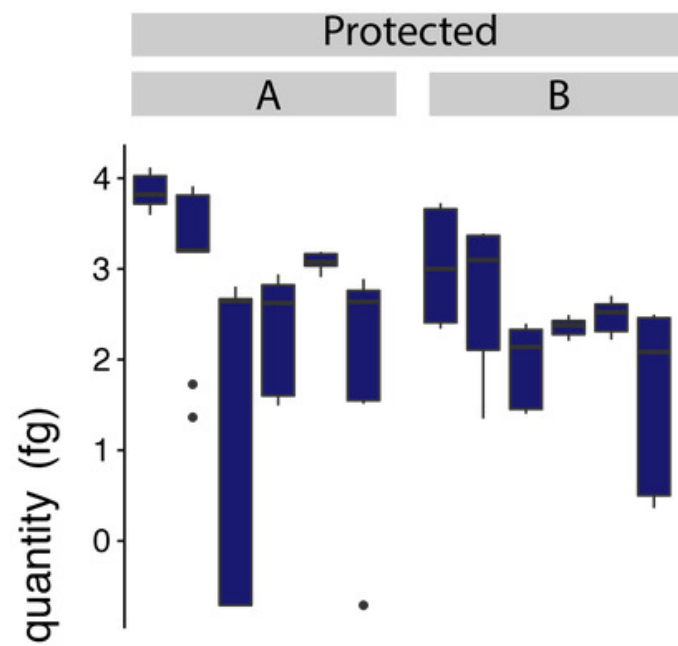

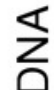

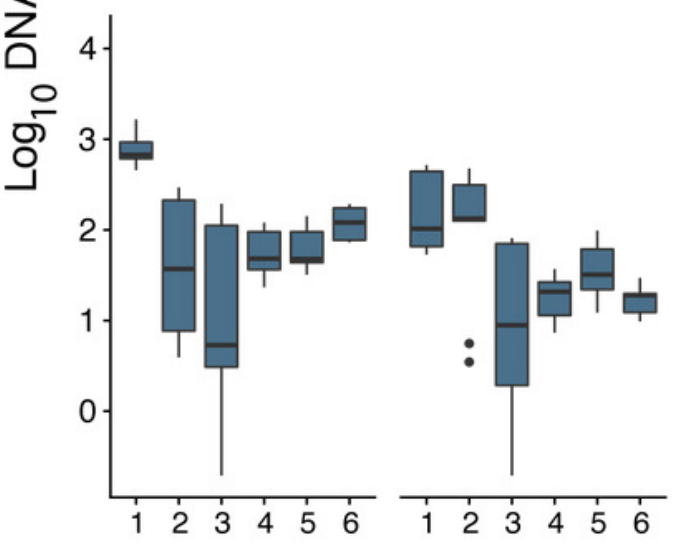

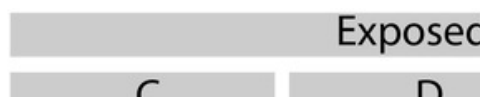

C

D

$\mathrm{E}$
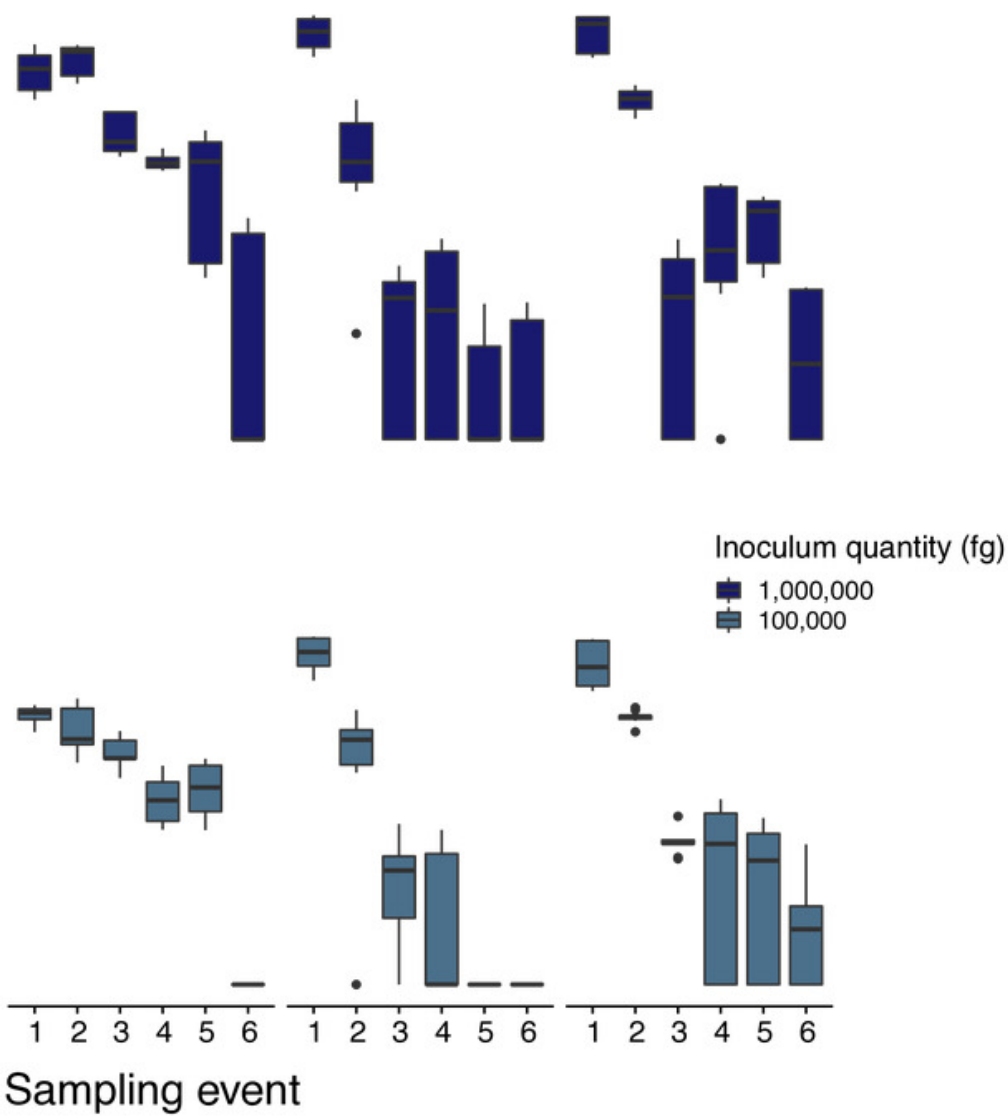
Figure 4

Proportion of positive samples of Pseudogymnoascus destructans detected during all sampling events.

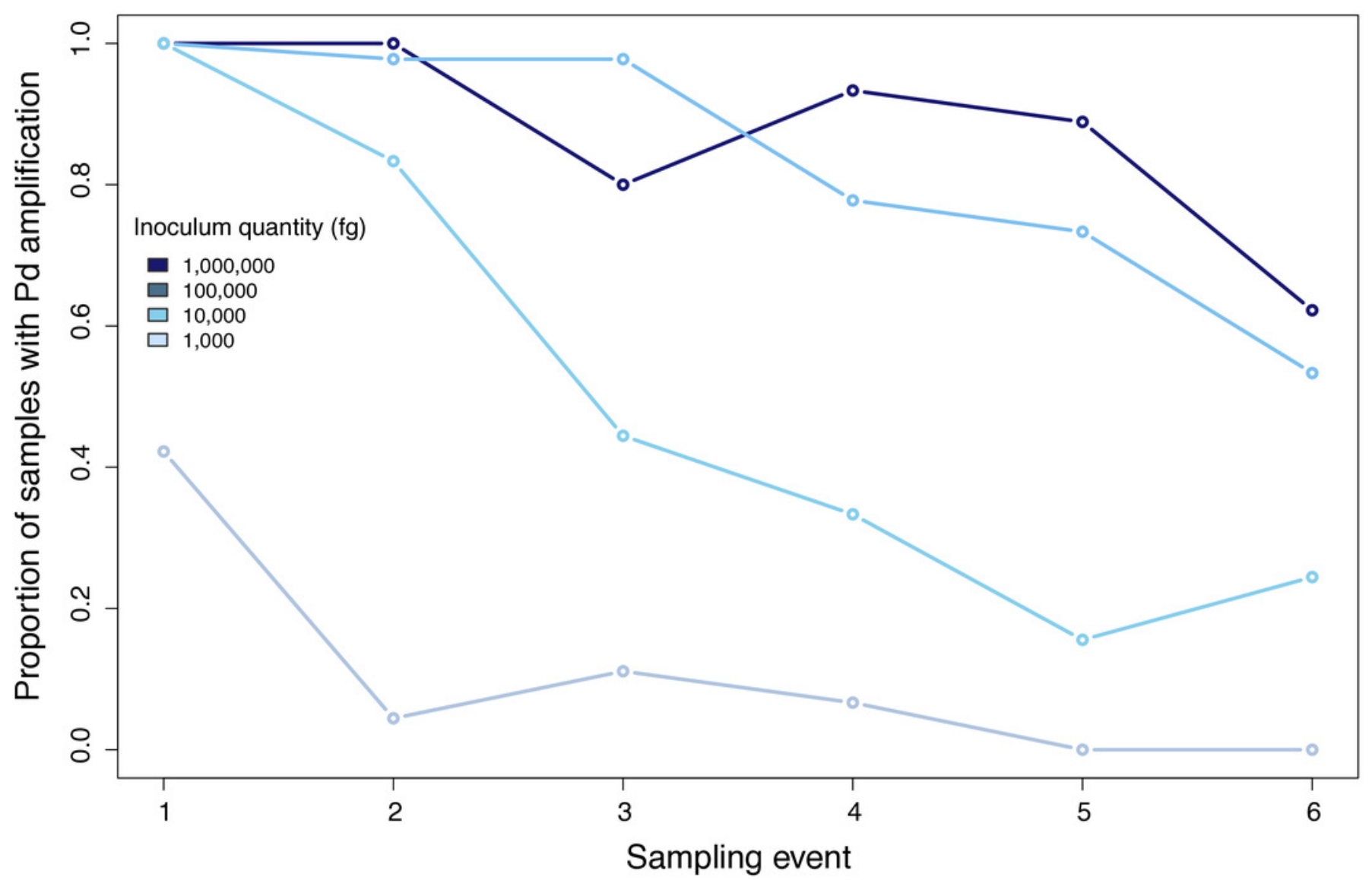


Figure 5

Model projections for detectable quantity of Pseudogymnoascus destructans for 100 days according to different quantities of inoculum.

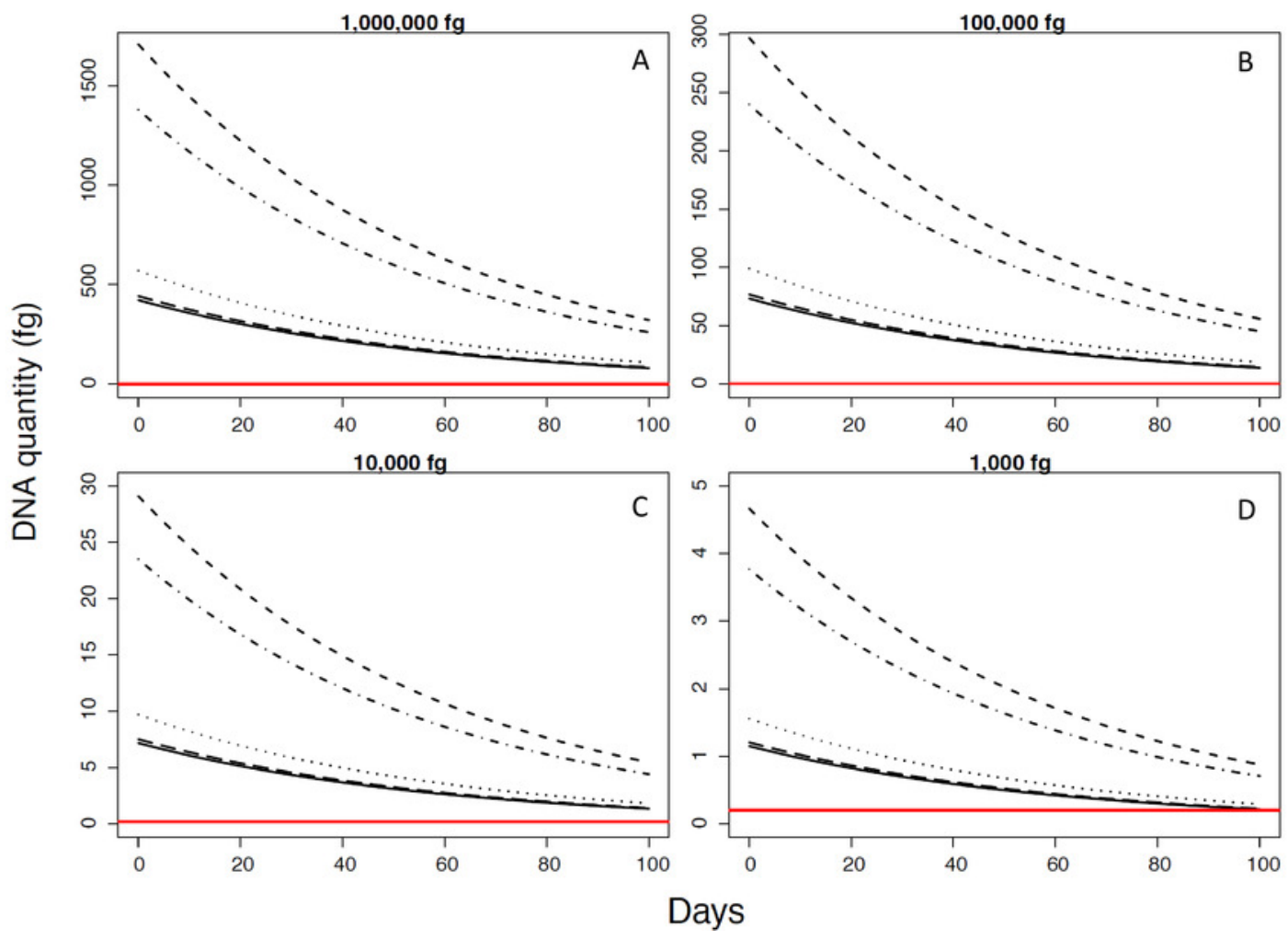




\section{Table 1 (on next page)}

Number of samples (percentages) that amplified during each sampling event. Total number of samples per sampling event $=15$. 
1

\begin{tabular}{lllllll}
\hline Sampling & $\mathbf{1}$ & $\mathbf{2}$ & $\mathbf{3}$ & $\mathbf{4}$ & $\mathbf{5}$ & $\mathbf{6}$ \\
& Day 1 & Day 13 & Day 29 & Day 42 & Day 56 & Day 70 \\
$\begin{array}{l}\text { Inoculum quantity } \\
\text { (fg) }\end{array}$ & & & & & & \\
\hline $\mathbf{1 , 0 0 0 , 0 0 0}$ & $15(100 \%)$ & $15(100 \%)$ & $12(80 \%)$ & $14(93 \%)$ & $14(93 \%)$ & $10(66 \%)$ \\
$\mathbf{1 0 0 , 0 0 0}$ & $15(100 \%)$ & $15(100 \%)$ & $15(100 \%)$ & $12(80 \%)$ & $11(73 \%)$ & $8(53 \%)$ \\
$\mathbf{1 0 , 0 0 0}$ & $15(100 \%)$ & $13(86 \%)$ & $8(53 \%)$ & $6(40 \%)$ & $3(20 \%)$ & $5(33 \%)$ \\
$\mathbf{1 , 0 0 0}$ & $9(60 \%)$ & $1(6.6 \%)$ & $2(13.33 \%)$ & $1(6.6 \%)$ & 0 & 0 \\
\hline
\end{tabular}

2

3 


\section{Table 2 (on next page)}

Amount of DNA $(\mathrm{fg})$ that can be detected at time 0 per site sampled with a mean weight of sample. 
1

\begin{tabular}{llllll}
\hline $\begin{array}{l}\text { Inoculum } \\
\text { quantity (fg) }\end{array}$ & $\begin{array}{c}\text { Nisqually } \\
\text { Site 1 }\end{array}$ & $\begin{array}{c}\text { Nisqually } \\
\text { Site 2 }\end{array}$ & $\begin{array}{c}\text { Ohanapecosh } \\
\text { Site 1 }\end{array}$ & $\begin{array}{c}\text { Ohanapecosh } \\
\text { Site 2 }\end{array}$ & $\begin{array}{c}\text { Carbon } \\
\text { River } \\
\text { Site 1 }\end{array}$ \\
\hline $\mathbf{1 , 0 0 0 , 0 0 0}$ & 421.48 & 1708.71 & 570.04 & 1380.02 & 441.51 \\
$\mathbf{1 0 0 , 0 0 0}$ & 73.25 & 296.98 & 99.07 & 239.85 & 76.73 \\
$\mathbf{1 0 , 0 0 0}$ & 7.18 & 29.11 & 9.71 & 23.51 & 7.52 \\
$\mathbf{1 , 0 0 0}$ & 1.15 & 4.66 & 1.55 & 3.77 & 1.20 \\
\hline
\end{tabular}

2

3 